\title{
Kilka uwag o wierszach czasu ostatniego bezkrólewia
}

Wojciech Kaliszewski 
nAPIS Seria IV 1998

\section{Wojciech Kaliszewski}

\section{Kilka uwag o wierszach czasu ostatniego bezkrólewia}

$\mathrm{P}$ oezja polityczna drugiej połowy osiemnastego wieku coraz częściej przyciąga uwage badaczy. Wydobywane $z$ rozproszenia i zapomnienia druki ulotne fascynują przede wszystkim jako znamienny przykład uwikłania literatury w wydarzenia całkowicie wobec niej zewnętrzne i zarazem wyjątkowo kryzysowe ${ }^{1}$. To zainteresowanie objawia się zarówno w przedsięwzięciach edytorskich, jak i w próbach opisu historycznoliterackiego odkrywanych zjawisk. Stałe i systematyczne uzupełnianie bloku poezji okolicznościowej drugiej połowy osiemnastego stulecia już teraz pozwala w miarę pewnie połączyć poszczególne ogniwa wierszowanego komentarza do ówczesnych, zwykle dramatycznych wydarzeń politycznych ${ }^{2}$.

Zasoby archiwalne kryją jeszcze interesujące — dla badacza tej problematyki - teksty, chociaż ostatnie kwerendy potwierdzają raczej przypuszczenia, że większych materiałowych rewelacji trudno się spodziewać. Tak więc nie rezygnując z poszukiwań, historyk literatury winien przejść do lektury tekstów, które udało mu się zebrać. I tutaj warto zadać pytanie o cel penetrowania tej właśnie gałęzi literatury. Pytanie to ma nie byle jakie znaczenie, zwłaszcza wobec głosów sceptyków kwestionujących sensowność i przydatność badań tej dziedziny. Otóż poza wszelkimi innymi celami, wynikającymi choćby z poznawczej dociekliwości i rzetelności, jeden wydaje się niezwykle istotny. Myślę o przydatności badań nad okolicznościową poezją polityczną do lepszego poznania intelektualnej i emocjonalnej formacji spo-

\footnotetext{
1 Por. E. Rostworowski, Historia pouszechna. Wiek XVIII, Warszawa 1977, część IV, s. 673-683.

${ }^{2} \mathrm{Na}$ ten temat zob. E. Rabowicz, Okolicznościowa literatura polityczna, [w:] Stownik literatury polskiego ośuiecenia pod red. T. Kostkiewiczowej, Wrocław 1991, s. 338-351; tam bibliografia przedmiotu. Zob. także J. Maciejewski, $Z$ problematyki badań nad okolicznościowa poezja polityczna 1763-1788, [w:] tenże, Obszary i konteksty literatury, Warszawa 1998, s. 24-38.
} 
łeczności przeżywającej tamte wydarzenia. W tej poezji kryje się ciekawy sposób myślenia i reagowania na rzeczywistość. Narodzinom wierszy politycznych towarzyszą zawsze napięcia charakteryzujące zarówno indywidualności, jak i całą złożoną zbiorowość szlachecką. W poezję polityczną — od XVI wieku poczynając jest ona trwałym składnikiem literatury wpisane są przecież wartości i postawy w sposób oczywisty budujące mentalność szlachecką.

Utwory okolicznościowe powstawały i funkcjonowały najczęściej poza strukturami kultury elitarnej. Tym samym dystans między nadawcą a odbiorcą ulegał istotnej redukcji. Znaczenia ukryte w tekstach modyfikowała konwencja polemiki ustnej, która słabo (lub prawie wcale) akcentowała walory artystyczne wypowiedzi, zwracając przede wszystkim uwagę na jej polemiczną skuteczność.

Wiersze czasu ostatniego bezkrólewia dotyczą wydarzeń lat 1763 i 1764 . W ocenie historyków sytuacja po wojnie siedmioletniej w całym rejonie Europy Środkowej, której centrum była Rzeczpospolita rządzona przez Wettinów, stała się niezwykle napięta i kryzysowa. Coraz ostrzejszy spór pomiędzy przymierzem „państw południowych” a przymierzem „państw północnych" wyznaczał twardą linię podziału politycznego i zarazem religijnego. Polska w tej grze nie miała juz praktycznie samodzielnej roli. O rozwiązywaniu jej wewnętrznych problemów decydowały obce dwory. Wettinowie tracili polityczne znaczenie. Szczególnie po usunięciu z Kurlandii księcia Karola, syna Augusta III przez cara Piotra III, nikt już z Sasami poważniejszych nadziei nic wiązał. Rosja rozpoczynała wyraźnie nowy etap stosunków z Polską, tym razem w kontekście porozumienia z Prusami. Tak więc to, kto zasiądzie na polskim tronie, ostatecznie rozstrzygnięto w Petersburgu, pozwalając Polakom na działania pod kontrolą oraz na czysto słowne spory i utarczki ${ }^{3}$.

W samej Polsce antysaska opozycja czekała na śmierć Augusta III z niecierpliwością. Na jej czele stali książęta Czartoryscy. Ostatnie lata panowania nieudolnego i schorowanego monarchy sprzyjały ich planom politycznym. Zręcznie wykorzystując - przynajmniej przed rokiem 1763 - sytuację międzynarodową, a głównie sytuację dworu petersburskiego, Czartoryscy przystąpili do działania. Petersburski zamach stanu wyniósł na tron Katarzynę II, która uwagę swojej polityki zagranicznej skupiła właśnie na Polsce — potrzebne jej było lojalne stronnictwo w Rzeczypospolitej i w konsekwencji sterowanie tronem polskim. Na przełomie 1762 i 1763 Czartoryscy poważnie myśleli o konfederacji, której celem byłoby „usunięcie nadużyć" i przywrócenic ładu w Polsce. Hasła reform i wszelkiego rodzaju „napraw” wspierały polityczne scenariusze niezwykle skutecznie. Do detronizacji Augusta III jednak nie doszło, ostatecznie Katarzyna nic spieszyła się z usunięciem Wettina, prowadząc ponad glowami Familii własną grę polityczną.

Czartoryscy planując przewrót okazywali się aktywni nie tylko w gabinetach, ale również jako twórcy programu ratowania narodowego i państwowego bytu Polski. Miało to być

${ }^{3}$ Por. W. Konopczyński, Dzieje Polski now oźytnej, t. 2, Warszawa 1986, s. 176-254. 
„nowe, albo powtórzone świata polskiego tworzenie”. Wokół przywódców Familii skupily się umysły i talenty zdolne sformułować interesujący program naprawy w sposób wyrazisty i literacko interesujący. Niebagatelną kwestią było pozyskanie jak największego grona zwolenników. Temu celowi miał służyć między innymi tak zwany „mały” "Monitor” ukazujący się późnym latem roku 1763 z inicjatywy A. K. Czartoryskiego. W „małym” Monitorze pisywał między innymi Stanisław Konarski. Początkowo związany z hetmanem Janem Klemensem Branickim, po jego porozumieniu z „republikantami” zbliżył się do Czartoryskich, stał się ważną postacią ich teatru politycznego. Przeciwnikom jawił się jako ktoś bardzo niebezpieczny. Wielokrotnie radzono mu, aby zamiast kwestiami publicznymi zajął się zakonem.

Należy przy tym pamiętać, że w roku 1763 „mały” Monitor stanowił ważne źródło kształtowania opinii szlacheckiej i ostatecznie dopomógł Czartoryskim do zwycięstwa w roku 1764. Krążył nie tylko w formie druczków ulotnych, ale również w licznych odpisach ${ }^{5}$.

Król August III zmarł 5 października 1763 roku w Dreźnie, tuż przed planowanymi obchodami trzydziestolecia zasiadania na tronie ${ }^{6}$. W Polsce naprzeciwko siebie stançły dwa stronnictwa, dwie „fakcje” od dawna przygotowujące się do generalnego starcia o tron. Obydwie odwoływały się zresztą często do tych samych, czy utrzymanych w podobnym tonie argumentów. Przeciwnikami Czartoryskich byli głównie Potoccy, którzy najpierw popierali elektora saskiego, a po jego śmierci wysuwali kandydaturę hetmana Branickiego.

W tej grze liczyły się nastroje społeczności szlacheckiej, była to przecież potężna, blisko dwustutysięczna armia niezwykle czułych i wrażliwych na wszystko, co dotyczyło szlacheckiego status quo, obywateli.

Interreks prymas Eubieński stanął po stronie Czartoryskich i w listopadzie 1763 roku — sprzyjając planom Familii - wyznaczył niezwykle odległy termin konwokacji, bo aż na 7 V 1764 r. Dawalo to Czartoryskim czas na przygotowanic kampanii elekcyjnej oraz na zneutralizowanie saskich sentymentów. Już w lutym przewaga Czartoryskich w sejmowych wyborach stała się faktem. Niewątpliwą przyczyną wzrostu siły Familii była śmierć ewentualnego pretendenta do tronu polskiego, najstarszego syna Augusta III, Fryderyka Christiana zmarłego w grudniu 1763 r. Zdecydowane działania sejmu konwokacyjnego, którego marszałkiem został Adam Czartoryski, odebrały Potockim i ich zwolennikom możliwość skutecznego oporu. Niewymownym argumentem były faktycznie rosyjskie bagnety. Jasne stawało się, że na objęcie tronu polskiego szansę ma tylko kandydat Familii.

Ostatnie interregnum to rzeczywisty prolog dramatu, który zakończył się tragiczną sceną roku 1795. Polityczna agonia Rzeczypospolitej, tylekroć analizowana i komentowana przez historyków ma swój dosłownie agonalny zapis w bogatej okolicznościowej literaturze poli-

\footnotetext{
4 Zob. ibidem.

5 Zob. R. Kaleta, „Monitor” z roku 1763 na tle swoich czasóu, [w:] tenże, M. Klimowicz, Prekursorzy Oświecenia, Wrocław 1953, s. 5-217.

${ }^{6}$ Zob. J. Staszewski, August III, Warszawa 1986, zwł. s. 42.
} 
tycznej. Jeśli spojrzeć na ostatnie bezkrólewie z tej właśnie perspektywy, to wypadnie stwierdzić, że był to może niezbyt obszerny, ale za to niezwykle ważny rozdział historii piśmiennictwa. Wiersze czasu ostatniego bezkrólewia stanowią, poza wyrażaniem nastrojów chwili, pierwsze ogniwo literackiej wizji Polski. Bez uwzględnienia tego etapu pełna interpretacja literatury okresu stanisławowskiego, a także i czasów późniejszych byłaby niemożliwa. W latach 1763-1764 tworzy się nowy model literatury okolicznościowej. Zmiana wyrażała się nie tyle $\mathrm{w}$ nowej stylistyce - ta pozostawała raczej tradycyjna — ile w poruszaniu kwestii wolności. To właśnie wtedy, w momencie sporu o przyszłego króla i tuż po obiorze Stanisława Poniatowskiego pojęcie wolności tradycyjnie związane z mentalnością szlachecką zaczyna odnosić się do niepodległego istnienia państwa. Warto więc pamiętać o prekursorskiej roli wierszy ostatniego bezkrólewia wobec narodzin nowego typu patriotycznej literatury.

Wydarzenia i konsekwencje wypadków z lat 1763-1764 nie znikają z pola tematycznego literatury okolicznościowej wraz z elekcją Stanisława Poniatowskiego. Trzeba podkreślić, że poczynając od XVI wieku, od czasów pierwszego bezkrólewia spory i polemiki przybierające postać form okolicznościowej literatury politycznej właściwie wygasały po rozwiązaniu konfliktu. Utwór okolicznościowy wiązał się z aktualnym wydarzeniem w ściśle określonym czasie. Jego sens w innym kontekście nie musiał być wcale czytelny.

Naturalnym ciągiem dalszym okolicznościowej literatury politycznej ostatniego bezkrólewia są utwory postałe około roku 1767 . Oto Siedem psalmów, w których Wolność Polska czyni lamentacja nad upadkiem swoim. W psalmie pierwszym upersonifikowana „Wolność Polska” taką oto zglasza skargę:

Dzieci moje w sieroctwie moim po Auguście Trzecim udręczyli mnie bez litości.

Rzekli w sercach swoich: zburzmy wolność, panujmy sami. Weźmiemy w poddaństwo braci naszych, niewolnikami naszymi uczyńmy ich.

Napełnili żołnierzami stolicę moją Warszawę, podbili ją w sieroctwie moim na konwokacją ${ }^{7}$.

Elekcja Poniatowskiego przypominana jest w związku z dramatycznymi wydarzeniami drugiej polowy lat sześćdziesiątych jako początek klęsk ojczyzny. Ten sam psalm pierwszy kończy się taką oto apostrofą uosobionej „Wolności Polskiej”:

Wejźrzyj Panie na utrapienie moje, pospiesz się do wybawienia mnie a połam kajdany moje. Z karku mego zdejm jarzmo nieznośne ${ }^{8}$.

Wszystkie wydarzenia polityczne po roku 1764 stanowią logiczny ciąg wynikający z obioru Poniatowskiego, a okolicznościowa literatura czasów stanisławowskich stanowi czytelną

7 Literatura barska (Antologia), opr. J. Maciejewski, Wroclaw 1976 (BN I 108), s. 6.

${ }^{8}$ Ibidem, s. 7. 
całość dopiero po włączeniu w jej obręb utworów z lat 1763-64. Wyraźnie chcę podkreślić, że stosowane dotychczas kryterium podziału chronologicznego traci pierwszoplanową rolę. Oto zamiast izolowanych i wyodrębnionych zjawisk w polu naszej uwagi pojawia się dynamiczny proces wnikający w wiek XIX ${ }^{9}$.

Od czasów ostatniego bezkrólewia literatura o tematyce obywatelskicj i patriotycznej nabiera szczególnego wymiaru. Literatura przestaje wyrażać tylko i wyłącznie chwilowe racje, staje się czytelnym znakiem, zyskuje perspektywę symboliczną.

Tematycznie literatura ostatniego bezkrólewia obejmuje trzy zasadnicze kręgi. W centrum pierwszego stoi zmarły król August III, bohaterem drugiego jest Stanisław August Poniatowski, a trzeci skupia się wokół wizji przyszłej Polski.

Do grupy pierwszej należy zbiór epitafiów na śmierć Augusta III — w tym Wiersze uskarżające się na śmierć Najjaśniejszego Króla Imci Augusta III ${ }^{10}$. Żal po śmierci Sasa łączy się $z$ niechęcią do zapowiadanych zmian i reform wiążąc je — nie bez racji — w tym momencie z obcym, faktycznie nieprzyjaznym Polsce poparciem. Z drugiej strony właśnie to, co było znane, co dawało poczucie bezpieczeństwa, podważyła śmierć Augusta III. Panowanie Wettinów kojarzono - naiwnie — z gwarancją istnienia prawdziwie wolnej Polski.

Ale już liczący grubo ponad sto wersów utwór Filozofia Augusta III po śmierci - rodzaj pośmiertnej spowiedzi — obnaża przewrotną naturę Sasa. Autor — niewątpliwie przeciwnik Augusta III - przypomina haniebne wygnanie legalnie wybranego króla Stanisława Leszczyńskiego. Obaj monarchowie spotykają się zresztą w fantazyjnym dialogu prozą z roku 1770, w Rozmowie na Polach Elizejskich królów polskich Augusta III i Stanistawa Leszczyńskiego ${ }^{11}$.

W sporze o przyszłą Polskę często głos zabierał „szczery patriota”, który jest prototypem późniejszego, gotowego na wszystko, a szczególnie skorego do działania w obronie ojczyzny, bohatera barskiego. To on właśnie opowiada się przeciwko kandydatowi saskiemu w Gtosie szczerego Patryoty podczas interregnum 1764 do Ojczyzny odpowiadającej ${ }^{12}$. Ów wierszowany dialog pomiędzy upersonifikowaną Ojczyzną i równie upersonifikowanym Echem glosu „szczerego patrioty" krążył w licznych odpisach, także pod tytułem Echo szczerego Patryoty podczas teraźniejszego Interregnum. Głos wymierzony w saskiego pretendenta do polskiego tronu stanowi zarazem dobitną krytykę oportunizmu Polaków. Wedle słów „szczerego patrioty” Polacy są nad wyraz „gnuśni” i przez to gubią Ojczyznę. Cios wymierzany Ojczyźnie - mowa o nim nie tylko w tym dialogu - to akt zdrady, jakiej dziecko dopuszcza się wobec rodzica. Ojczyzna-Matka stokrotnie bardziej cierpi od ran zadanych przez własne dzieci niż przez wrogów ościennych. „Nieszczęsna matko, jakie rodzisz dziatki” — lamentacyjny ton Echa

\footnotetext{
${ }^{9}$ Być może - chociaż jest to stanowisko kontrowersyjne - jednym z późnych etapów owego procesu byłyby Ksiegi narodu polskiego i pielgrzymstwa polskiego A. Mickiewicza.

${ }^{10}$ Rkps AGAD Sucha 81/100 s. 197.

"Filozofia Augusta III po śmierci pojawia się także jako Projekt pod tytutem August III po śmierci filozof, rkps BKórn. 1137 k. 19. Według najnowszych ustaleń Rozmowa ... powstała prawdopodobnie w roku 1770. Por. Rozmowy na Polach Elizejskich królów polskich, opr. J. Wójcicki, „Napis”, seria II, 1995, s. 58-100.

12 Rkps BKórn. 999 s. 41 (także pod tytułem Echo szczerego...).
} 
już wtedy, podczas ostatniego bezkrólewia silnie akcentuje złamanie świętej zasady miłości do Ojczyzny-Matki.

Ten sam motyw, tyle że wyrażony w znacznie bardziej przejmujących słowach, pojawia się w okresie barskim, w słynnej Lamentacji Jeremiasza nad Krakowem 1768 A.:

Godzien, żeby ten Judasz został obwieszony,

Iż w moskiewskie lud polski zdradą podal szpony.

Szatana ten Ojczyzny syn musiał być rodem, Jego szatańska sztuka jawnym jest dowodem ${ }^{13}$.

Zdrada, rozbicie świętej jedności z Ojczyzną, zobojętnienie i zgnuśnienie to objawy szczególnie groźnego zatrucia, choroby, którą trzeba jak najszybciej wyleczyć. Oto w Opisaniu pretendentów do korony polskiej z 8 lutego 1764 r. czytamy:

Że królem być nie możesz, a któż nie dociecze,

Gdy trują w sercach polskich wasze saskie miecze ${ }^{14}$

Warto zauważyć, że autorzy utworów okolicznościowych ostatniego bezkrólewia starają się także wskazać na przyczyny, które wywołały tak straszne zatrucie serc i umysłów Polaków. Najczęściej przywoływanym powodem jest postępujący upadek moralności i odpowiedzialności osobistej wynikający z osłabienia wiary. Ton tych wypowiedzi przypomina pouczenia surowych siedemnastowiecznych kaznodziejów. Świat istnieje o tyle, o ile opiera się na boskim porządku. Kto wierzy w Boga i kto boi się Jego Mocy, ten nigdy nie ulegnie pokusie sprzedania Ojczyzny dla doraźnych zysków. Przeczucie nadciągającego kryzysu przenikało wszystkie sfery życia. Apokaliptyczna i profetyczna stylistyka wykorzystywana była z wielkim powodzeniem przez autorów kreślących przyszłą perspektywę Polski. Do stałego repertuaru wyrażeń zaliczyć trzeba choćby takie jak: Gniew Boski, czy Kara Boska. Jakże wymowny staje się jeden z tytułów: Przyczyny Kary Boskiej w latach krytycznych na Królestwo Polskie po śmierci Augusta III Roku 1763.

Napięta sytuacja polityczna stawała się doskonałą okazją do szyderczych krytyk przeciwników, zwłaszcza jeśli ci piastowali wysokie godności kościelne. Wiersz satyryczny, skierowany przeciwko prymasowi Łubieńskiemu, poza szczególnym portretem jednej z pierwszych osobistości w kraju jest także i lamentem nad upadkiem prawdziwej duchowości:

Trzech się duchownych na nasz los zmówiło.

Bóg daj, by w Polszcze tej trójcy nie było.

Ducha Bożego schyzma odrzucaja.

Jak ma być dobrze, gdy światła nie mają ${ }^{15}$.

${ }^{13}$ Literatura barska, s. 241.

${ }^{14}$ Rkps Ossol. 316 II k. 76-76v.

is Rkps Bibl. Jag. 111. 
Podobnej retoryki oraz argumentów odwołujących się do tych samych emocji używali z ogromnym zresztą powodzeniem - przeciwnicy Familii. Tematem szyderstw i złośliwości był herb Stanisława Poniatowskiego - ciołek. W zbiorze Wierszy na Jm Pana Poniatowskiego Stolnika Litewskiego majacego za herb Ciolka, starajacego sięo koronę 1764 Ciołek porównany został do starotestamentowego cielca, któremu tak latwo ulegli bezwolni Żydzi, niepomni na obecność jedynego i prawdziwego Boga:

Chce się Poniatowskiemu, by go królem zwano

I koroną ciołkową głowę uwieńczano.

W starym to Testamencie ten zwyczaj wskrzesili, Że czasem za swych bogów Żydzi ciołków czcili.

Nie wzbudzą nas tej wiary w Polszcze cielcy tacy,

Bośmy nie nędzni Żydzi, lecz mężni Polacy ${ }^{16}$.

Poniatowskiego przedstawiano jako wyraźne zaprzeczenie postaci „szczerego patrioty”. Bardzo mocno podkreśla się bezpodstawność protensji do korony. W oczach przeciwników Poniatowski staje się symbolem upadku wiary i wolności. Utrzymane w tym tonie i w tej stylistyce ataki na Poniatowskiego będą się powtarzały często także po roku 1764.

Wiersze przedstawiające kandydatów do tronu polskiego tworzyły czasami ciekawe dialogi. Warto w tym miejscu przypomnieć, że w literaturze okolicznościowej dialog — jako stara i sprawdzona forma polemiczna - pojawia się często. W przywoływanych Wierszach na pretendenta do korony spotkamy się z ciekawymi odpowiedziami tym, którzy kpili z Poniatowskiego:

Z Ciołków pochodzącego senatora ganić,

Ciołka takie jest zdanie: rozum twój chcesz mamić,

Który gdy Izraela przywodzisz ofiary,

Nie tej ci są Polacy z zdania twgo wiary.

Rozumiesz, że tak ciołek jako twoje zdanie.

Mylisz się, nie tak drudzy swe mają mniemanie.

Niech będzie królem Ciołek, wszyscy mu życzemy,

Będzie pokój w Koronie, którego pragniemy,

Gdy zaś ciołek jako ty zabeczy w koronie,

Nie rozumnym, lecz głupiej będzie miejsce wronie ${ }^{17}$.

${ }^{16}$ Cyt. za B. Kaniecka, Niewydane wiersze polityczne z czasów ostatniego bezkrólewia i Sejmu Czteroletniego, „Prace Polonistyczne" XXVII, 1971, s. 287. Przytoczone wiersze pochodzą ze znajdującej się w łódzkim Archiwum Bartoszewiczów sylwy sygn. 431, jej właścicielem był Ksawery Józef Wąż. W księdze znajduje się około 30 tekstów tematycznie związanych z ostatnim bezkrólewiem, konfederacją radomską i barską.

17 Ibidem, s. 287. 
Zmiana monarchy rodzi nadzieję na przywrócenie praworządności i tolerancji. W słowach pełnych otuchy, zachęty do pojednania i prowadzenia dialogu autor Kolędy szlachcie ruskiej na rok pański $1764 \ldots{ }^{18}$ zwraca uwagę na konieczność dopuszczenia do głosu szlachty unickiej. Animozje religijne stanowiły wiecznie tlące się zarzewic konfliktów. Zwróćmy uwagę, że ocena kandydatów do tronu i ich zwolenników także odwołuje się często do argumentów natury religijnej. W Kolędzie, którą na interregnum ofiarowuje „Anonim Szlachcic Rusin Unita” słychać i skargę na odsuwanie szlachty unickiej od głosu, i pouczenie tym, którzy opacznie rozumieją istotę narodu:

Rusin bowiem, tak jak Niemiec,

Francuz, Anglik, cudzoziemiec -

Naród znaczy, a nie wiarę,

Więc przebaczy, kto maszkarę

Tę przypisuje Rusi.

Nowy monarcha ma więc stać na straży demokratycznego porządku, kolęda jest pieśnią wiary w odrodzenie człowieka i świata. Swoje racje autor wykłada w toku dydaktycznego wywodu, nie dbając przy tym specjalnie o poziom języka poetyckiego wypowiedzi:

Nie zgiełk, rozruch, tumult, zwada,

Lecz w pokoju i miłości

Domagać się cnej równości,

Na co pora obfita,

Gdy Korona owdowiała

Zgromadzoną będzie miała

Radę o nowym krolu

$\mathrm{Na}$ elektorskim polu.

Wtenczas w pacta conventa,

Gdzie się wszystko poprawuje,

Co poprawy potrzebuje,

Mocno o to usiłować,

Kosztu, pracy nie żałować,

By ta sprawa przyjęta:

Aby szlachta Ruś unici

W swej ojczyźnie znamienici,

Urzędami, dochodami

Porównani z Polakami,

Duchowni z duchownymi,

${ }^{18}$ Ibidem, s. 286. 
O czym każdy niechaj myśli,

Bo wiersz tego nie okréśli.

Zdecydowanie koncyliacyjny ton Kolędy odbiegał od ostrych i pełnych oskarżeń portretów „pretendentów”. Zdarzało się przecież i tak, że przeciwnicy stosowali wobec siebie nieco lagodniejsze formy wypowiedzi. Liczne zbiory wierszy Na pretendentów do korony polskiej po śmierci Augusta III ${ }^{19}$ krążyły obok polemik, w których racjom „Litwina”, czyli Augusta Czartoryskiego przeciwstawiono argumenty „Korończyka” — w rzeczywistości hetmana Jana Klemensa Branickiego. Wśród wierszy znalazły się także wróżby — jedne przepowiadające koronę Czartoryskiemu, inne widzące na tronie Branickiego, jak choćby Kabała litewska o królu i Korończyka odpowiedź:

Osieroconej bez króla koronie

Wsadzą nam na tron następcę Pogonie 20

— replikując zwolennicy Branickiego zakładali, że:

Słusznie po Janie trzecim Klemens Jan król czwarty ${ }^{21}$

Ostatnie bezkrólewie zaowocowało także wierszami o nastrojach katastroficznych. Powtarza się wizja „Orła polskiego” rozszarpywanego przez inne, złe, obce, czarne orly. Lęk przed przyszłością stanowi istotny składnik treści utworów związanych z bezkrólewiem.

Polityczne wiersze apelujące do szlacheckiego rozsądku nierzadko - jak już wspominałem - przybierały postać dialogu. Ten szczególny przypadek polemicznych rozmów miał w osiemnastym stuleciu ciekawą, szkolno-dydaktyczną tradycję. W swoich kolegiach pijarzy a na to właśnie zgromadzenie przychylnie spoglądali Czartoryscy i jemu powierzali kształcenie synów - wprowadzili zwyczaj publicznego przedstawiania „rozmów”. Były to przygotowywane przez uczniów pod kierunkiem profesorów, dialogowane wypracowania na konkretne tematy. Na przykład w roku 1757 w warszawskim Collegium Nobilium rozmawiano o „uszczęśliwieniu własnej ojczyzny”. Te ćwiczenia ukazały się drukiem i kolejno w latach 1760, 1761 i 1762 wydano trzy tomy Rozmów w 'iekawych i potrzebnych, $w$ filozoficznych i politycznych materyach, $w$ Collegium Nobilium warszauskim Scholarum Piarum miane 22 . Na takim warsztatowym fundamencie stronnicy Familii niewątpliwie budowali swoje wypowiedzi. Kiedy na przykład krytykowali "gnuśność” Polaków, przywoływali jakby wprost zasady wpajanc w kolegiach pijarskich. A powiadano tam wyraźnie, że oprócz obowiązków wobec Boga, religii i rodziców „zacność człowieka polega też na wykonywaniu powinności względem ojczyzny”.

\footnotetext{
${ }^{19}$ Istniały liczne warianty wierszy prezentujących kandydatów do tronu. Por. rkps Sucha 81/100, Ossol. 316 II, k. 76.

${ }^{20}$ Rkps Bibl. Jag. sygn. 4894 II, k. 35.

21 Ibidem, k. 36.

22 Por. W. Smoleński Przewrót umystoury w Polsce wieku XVIII. Studia historyczne, Warszawa 1949, s. 30.
} 
Skargi, żale, lamentacje, portrety, dialogi podsuwały autorom gotowe wzorce wypowiedzi. Odbiorca wychowany na ogół w tej samej tradycji literackiej, z jakiej korzystał autor, doskonale rozumiał język, w którym zwracano się do niego. Ale podobieństwo haseł, pokrywanie się argumentów, te same zwroty i wyrażenia płynące z różnych — wrogich — obozów wywoływały chaos w szlacheckich głowach. Charakterystyczny pod tym względem jest wiersz Lament Jey Mci Pani Hetmanowej ${ }^{23}$ — podziały polityczne dzielą rodziny. W końcu nie wiadomo, kto ma naprawdę rację. W wypowiedziach płynących z przeciwstawnych źródeł pojawiają się te same hierarchie wartości. W kręgu wartości pozytywnych jest więc zawsze Bóg, wiara, religia (przeważnie katolicka) - dzięki nim otwiera się perspektywa transcendentna, w której sprawa przyszłego króla nabiera specjalnego znaczenia. Tuż obok ważne miejsce zajmują wartości patriotyczne - ojczyzna, naród, polskość, szlachectwo. Wśród wartości negatywnych znajdą się krytykowani kandydaci do korony, sprzedajni dygnitarze jak wspomniany prymas Łubieński - obce wojska, innowiercy, czy w końcu obce dwory i obcy monarchowie ${ }^{24}$.

Takie zróżnicowanie hierarchii łączy się z wykorzystywanie stylu i tonu biblijnego w wierszach okolicznościowych. Bardzo ciekawym, nawiązującym do biblijnych dziejów jest obszerny utwór Prawda $w$ Polszcze $z$ Izraela $w$ rozdzialach $16^{25}$, napisany „we dni Stanisława roku piątego miesiąca czwartego królestwa jego w ziemi Lecha", a więc już po interesującym nas bezpośrednio okresie. Ale ten właśnie — bogaty także w apokaliptyczne obrazy — na poły historyczny, na poly profetyczny utwór sięga wydarzeń roku 1763 . Oto przed nami jakby na nowo spisane dzieje, na wzór dziejów Izraela, pełne symbolicznych znaczeń. Cały rozdział trzeci jest opowieścią o sporach i kłótniach wokół kandydatów do korony po śmierci Augusta III. Jedyną szansą na przezwyciężenie kryzysu jest przestrzeganie nakazu jedności wiary i myśli: „A gdzie rozmaitość i różnorodność mniemania, tam pomieszanie duszy blądzącej, przy której zaiste nic jest światło prawdy aż do skończenia świata”. W końcu powiada się, że najlepszym z kandydatów jest Stanisław Poniatowski i to wokół niego powinni skupić się wszyscy kochający wolność i Polskę.

W tej chwili blok wierszy politycznych z czasów ostatniego bezkrólewia liczy ponad czterdzieści tytułów zarówno pojedynczych utworów, jak i zbiorów zawierających po kilka lub kilkanaście - najczęściej epigramatycznych — wierszy. Prawie cały materiał pozostaje rozproszony w rękopisach. Ustalenie kompletnej listy tytułów oraz porównanie odmian i wersji tekstowych stanowi więc bardzo ważne zadanie.

Niewątpliwie bez przedstawienia okolicznościowej literatury ostatniego bezkrólewia tak zwane przedpole literatury barskiej pozostaje niepełne.

${ }^{23}$ Rkps Ossol. 316 II, k. 167.

${ }^{24}$ Podobnie zhierarchizowane wartości odnajdziemy w literaturze okresu barskiego.

${ }^{25}$ Rkps Ossol. 569 II, s. 331. 
Wybór Stanisława Poniatowskiego na króla nie rozładował — jak już mówiłem napięcia. Wydarzenia końca lat sześćdziesiątych - konfederacja radomska, a później konfederacja barska stanowiły logiczne następstwo podziału politycznego i emocjonalnego społeczności szlacheckiej, jaki nastąpił w roku 1763, po śmierci Augusta III. Wypadki z ostatniego bezkrólewia wciąż żyły w pamięci. W odpisach słynnej Profecji księdza Marka karmelity ${ }^{26}$ umieszczono - jako datę powstania - rok 1763. Tak silnie bowiem utożsamiano przepowiednie losów Polski z wydarzeniami tej właśnie chwili. Dopiero ustalenia Emanuela Rostworowskiego ostatecznie wyjaśniły kwestię datowania Profecji, przesuwając datę na początek roku $1767^{27}$.

Wiersze polityczne stanowią wyjątkowy rozdział literatury, także w ramach literatury okolicznościowej. Pewne jej cechy — sposób widzenia świata, język, charakter procesu powstawania i rozpowszechniania — pozwalają budować porównania z folklorem. Wyraźnie pisał o tym Juliusz Nowak-Dłużewski ${ }^{28}$. Trudno byłoby badaczowi oderwać ten typ literatury od szerokiego kontekstu kultury szlacheckiej i szlacheckiej mentalności, od tradycji literatury rękopiśmiennej i sylwicznej.

W przypadku wierszy okolicznościowych ostatniego bezkrólewia badacz rekonstruuje nie tylko pewien fragment obrazu literatury, ale — co może najciekawsze - typ osobowości, odkrywa człowieka.

\footnotetext{
${ }^{26}$ Literatura barska, s. 3-5.
}

${ }^{27}$ Zob. E. Rostworowski, Ksiqdz Marek i proroctwa polityczne doby radomsko-barskiej, [w:] Przemiany tradycji barskiej. Studia, Kraków 1972, s. 29-57.

${ }_{28}$ Por. J. Nowak-Dłużewski, Staropolska anonimou'a poezja polityczna, „Życie i Myśl” $1960 \mathrm{nr}$ 9-10, s. 49-60; zob. też J. Maciejewski, Folklor środowiskoury. Sposób jego istnienia, cechy uryodrębniające (na przykladzie "folklorı" szlacheckiego XVII i XVIII w.), [w:] tenże, Obszary i konteksty literatury, op. cit., s. 39-55. 